\title{
Legal Analysis on Malaysian Construction Contract: Conditional versus Unconditional Performance Bond
}

\author{
Azizan Supardi \& Hamimah Adnan \\ Department of Quantity Surveying \\ Faculty of Architecture, Planning and Surveying \\ Universiti Teknologi MARA, 40450 Shah Alam, Malaysia \\ Tel: 60-3-5521-1532 E-mail: zzan_65@yahoo.com \\ Jamaluddin Yaakob \\ Department of Quantity Surveying \\ Faculty of Built Environment \\ Universiti Teknologi Malaysia, 81310 Skudai, Johor, Malaysia \\ Tel: 60-7-557-6160Ｅ-mail: contrmgmt@yahoo.com
}

\begin{abstract}
In Malaysia, the question of whether the performance bond in a construction contract is a conditional or an unconditional guarantees is still one of the issues relating to performance bond. Therefore, the objective of this research is to determine the phrase(s) in the Performance Bond in a construction contract that determine whether the performance bond is a conditional or unconditional on demand guarantee. In order to achieve this objective, the research was conducted by analyzing relevant court cases. From the findings, it can be concluded that unless an undisputed meaning of the words in the performance bond to make the performance bond to be purely conditional or unconditional 'on-demand' bond, most court interpreted performance bond to be an on-demand performance bond which is only conditional upon the beneficiary asserting the basis of the claim upon the issuer of the bond contending that there has been breach of contract.
\end{abstract}

Keywords: Performance Bond, Guarantee, Conditional Bond, Unconditional on-demand Bond, Court Cases, Construction Contract, Malaysia

\section{Introduction}

A performance bond is a bond giving security for the carrying out of a contract, where a bond is a deed by which one person (the obligator) commits himself to another (the obligee) to do something or refrain from doing something (Martin, 2003). In construction contracts, a 'performance bond' is a bond taken out by the contractor, usually with a bank or insurance company (in return for payment of a premium), for the benefit of and at the request of the employer, in a stipulated maximum sum of liability and enforceable by the employer in the event of the contractor's default, repudiation or insolvency (Robinson et al. 1996). These relationships can be illustrated in Figure 1.

In Malaysia, most of the need of a performance bond is made through an agreement between the Government, the contractor and a third party (usually a bank or insurance company), whereby the third party agrees to pay a sum of money to the Government, in the event of non-performance of the construction contract by the contractor (Abdul-Rashid, 2004). It is provided in Clause 37(a) of the P.W.D. Form 203A (Rev. 10/83) Standard Form of Contract to be Used Where Bills of Quantities Form Part of the Contract that the Contractor shall either deposit with the Government a performance bond in cash or alternatively by way of a Treasury's Deposit or Banker's Draft or approved Banker's or Insurance Guarantee equal to $5 \%$ of the Contract Sum as a condition precedent to the commencement of work. In other words, the Contractor is not permitted to carry out any work under the Contract unless and until the performance bond is given. The failure of the Contractor to give the performance bond may amount to a fundamental breach of contract entitling the Government to discharge the Contract and sue the Contractor for damages accordingly (Fong, 2004a).

The validity period of the performance bond is as indicated in Figure 2 below. By clause 37(b), the performance bond is required to be maintained for such period as provided in the PWD Bond, i.e. until 6 months after the expiry of the Defects Liability Period stated in the Contract calculated from the date of completion of the Works or any authorized extension thereto or if the contract is determined, until one year after the date of determination (Fong, 2004a). 
There are two types of performance bonds, as set out below (Robinson et al. 1996).

- $\quad$ Conditional bond or default bond. A default bond is a contract of guarantee whereby the surety accepts 'joint and several' responsibility for the performance of the contractor's obligations under the building contract: the contractor remains primarily liable for his performance and not protected by the bond.

- $\quad$ Unconditional bond or on-demand bond. An on-demand bond is a covenant by the surety (usually a bank) to indemnify the employer following contractor's default, subject to stated terms and up to a sum commonly between 10 and $20 \%$ of the main contract sum. The contractor is not a party to this arrangement (under on-demand bond in Malaysia, subject to stated terms and up to a sum commonly $5 \%$ of the main contract sum).

The main distinction between the two types of bond is with respect to the requirements for making call on the bond. In conditional performance bond, the beneficiary must comply with conditions precedent for calling the bond. In on demand performance bond, on the other hands, the only condition precedent for calling the bond is a written notice to the guarantor.

Thus, in order to determine the types of performance bond applicable in a contract, a thorough understanding of the content of the bond is required. The Court of Appeal in the famous Teknik Cekap Sdn Bhd v Public Bank Berhad [1995] 3 MLJ 449 held that:

Therefore a performance bond is nothing more than a written guarantee, and in order to interpret the obligations of the bank, one need only to look at the written bond itself to determine what are the terms and conditions agreed upon between the parties. A great deal, therefore, depends on the wording of the bond itself.

However, in Malaysia, for the past 20 years and since the famous Teknik Cekap Sdn Bhd v Public Bank Berhad [1995] 3 MLJ 449 to the recent Suharta Development Sdn Bhd v United Overseas Bank (M) Bhd \& Anor [2005] 2 MLJ 762, the question of whether the performance bond in a construction contract is a conditional or an unconditional guarantees is still one of the issues relating to performance bond that been discussed.

In Suharta Development Sdn Bhd v United Overseas Bank (M) Bhd \& Anor [2005] 2 MLJ 762, Abdul Wahab Said Ahmad JC stated that:

A performance bond or guarantee is in fact a written contract to guarantee due performance in the event of breach or non performance of the contract. In determining whether it is conditional or otherwise, the court is concerned with the contractual construction or interpretation of the bond or guarantee itself. A great deal depends on the wording of the guarantee itself to discover the intention of the parties.

The defendant contended that the terms of the guarantee is conditional and cited Teknik Cekap Sdn Bhd v Public Bank Bhd [1995] 3 MLJ 449 whilst the plaintiff relied on LEC Contractors (M) Sdn Bhd (formerly known as Lotterworld Engineering \& Construction Sdn Bhd) v Castle Inn Sdn Bhd \& Anor [2000] 3 MLJ 339. In both the cases the terms of the bond are similar to that in the case before me. The Court of Appeal in Teknik Cekap Sdn Bhd held the bond to be conditional but in LEC Contractors (M) Sdn Bhd held it is an on demand bond.

In LEC Contractors (M) Sdn Bhd Mokhtar Sidin JCA distinguished the case of Teknik Cekap and at p 358 said:

That is the position of an on demand performance bond. It is clear to us that the bank guarantee in the present appeal is a performance bond. From the wordings of the guarantee it is clear to us that it is 'on demand' performance bond as stated in Esso Petroleum Malaysia Inc v Kago Petroleum Sdn Bhd: 'All that was required to trigger them was a demand in writing'; or in the words of Mohamed Dzaidin FCJ in the case of China Airlines Ltdv Maltran AirCorp Sdn Bhd: 'the guarantor will become liable merely when demand is made upon the beneficiary with no necessity for the beneficiary to prove any default by the principal in performance of the principal contract'.

The appellant claimed that the bank guarantee is a conditional bond. To support this contention learned counsel for the appellant referred to the case of Teknik Cekap, a decision of this court where the court held that a performance bond was a conditional bond. It was held by the court that because the bond began the words: 'If the subcontractor ... shall in any respect fail to execute the contract or commit any breach of his obligations thereunder then the guarantor shall pay'. Apparently this is the case in Malaysia where similar wordings has been used where the court has held that it was a conditional bond.

From the above case, therefore, it is important to determine the content of the performance bond: whether the client can call upon the bond in the case of non-performance of the contractor or can the bank restraint the client from calling the bond among other. So, the phrase(s) in the bond shall be the issue of discussion.

This phrase(s) should also be in written form. A clear written phrase(s) that make up the content of the performance bond can clear the distinction between conditional and unconditional on demand guarantee.

Hence it is important and necessary to understand the circumstances in performance bond, which will be available to the parties to a building contract. And from that, the parties involved will clearly defined their rights and liability against 
bonds and guarantee to assist the respective party in construction contract (Ismail, 2007).

As such, this research has the objective to determine the phrase(s) in the Performance Bond in a construction contract that determine whether the performance bond is a conditional or an unconditional on demand guarantee. By clearing this issue, it is hoped that no more dispute will arise under the interpretation of the content of the Performance Bond especially in a construction contract.

\section{Performance Bond}

The success of a construction project is measured by its timely completion to specification within the budget allocated. However, in the execution of any engineering project there is invariably an element of risk involved (Radhakrihnan, 1999): that is to say, construction is a highly risky business, where the level of risk is considered much higher than in other types of economic activities (Abdul-Rashid, 2004). Furthermore, projects involve commercial risks and they involve people (Murdoch and Hughes, 2000).

All parties take some form of risk when they enter into construction contract. The acceptance of an obligation brings with it the acceptance of a commensurate risk, i.e. the risk of being unable to fulfill the obligation because one's own inadequacy, incapacity, inadvertence or error, or because of interference from outside sources or supervening events (Robinson et al. 1996).

The following examples summarize many of the risks (Murdoch and Hughes, 2000). Some of them are contractor's risks (for example: payments; price fluctuation; etc.) and some are employer's risks (for example: workmanship; materials and goods; insolvency; etc.):

- $\quad$ Physical works - ground conditions; artificial obstructions; defective materials or workmanship; tests and samples; weather; site preparation; inadequacy of staff, labour, plant, materials, time or finance.

- Delay and disputes - possession of site; late supply of information; inefficient execution of work; delay outside both parties' control; layout disputes.

- Direction and supervision - greed; incompetence; inefficiency; unreasonableness; partiality; poor communication; mistakes in documents; defective designs; compliance with requirements; unclear requirements; inappropriate consultants or contractors; changes in requirements.

- Damage and injury to persons and property - negligence or breach of warranty; uninsurable matters; accidents; uninsurable risks; consequential losses; exclusions, gaps and time limits in insurance cover.

- $\quad$ External factors - government policy on taxes, labour, safety or other laws; planning approvals; financial constraints; energy or pay restraints; cost of war or civil commotion; malicious damage; intimidation; industrial disputes.

- $\quad$ Payment - delay in settling claims and certifying; delay in payment; legal limits on recovery of interest; insolvency; funding constraints; shortcomings in the measure and value process; exchange rates; inflation.

- Law and arbitration - delay in resolving disputes; injustice; uncertainty due to lack of records or ambiguity of contract; cost of obtaining decision; enforcing decisions; changes in statutes; new interpretations of common law.

Risks are inevitable and cannot be eliminated. They can, however, be transferred (Murdoch and Hughes, 2000). One of the main roles of a contract is to distribute risks between the parties. Standard forms of contracts contained express risks distributing provisions. Risk transferring contracts commonly exist between the various parties concerned in construction (Robinson et al. 1996).

In the context of public infrastructure work in Malaysia, one major risk to the Government is non-performance of construction contracts by the contractors (Abdul-Rashid, 2004). A performance bond is a legal and management instrument used by employers to manage risk with respect to contractor's nonperformance.

\subsection{Nature of Performance Bond}

A bond or guarantee is an arrangement under which the performance of a contractual duty owed by one person (A) to another (B) is backed up by a third party (C). What happens is that $\mathrm{C}$ promises to pay $\mathrm{B}$ a sum of money if $\mathrm{A}$ fails to fulfill the relevant duty. In this context $\mathrm{A}$ is commonly known as the principal debtor or simply principal; $\mathrm{B}$ is called the beneficiary; and $\mathrm{C}$ is called the bondsman, surety or guarantor (Murdoch and Hughes, 2000).

In a construction contract, performance bond is also a three-party instrument between bondsman, the employer and the contractor. The agreement, however, binds the contractor to comply with the terms of a contract. If the contractor fails to perform the contract, the bondsman assumes the responsibility to indemnify the employer up to the maximum amount of the bond. The Bondsman's obligation to pay is now arises when called upon to do so by the employer.

The obligation to pay is, however, independent of the underlying contract. This is due to the fact that the performance bond is like a letter of credit and designed to release 'no quibble' cash to the beneficiary in the event the call on the bond. 
This is agreed by what Lord Denning MR said in Edward Owen Engineering Ltd v Barclays Bank International Ltd [1978] QB 159, [1978] 1 All ER 976, [1977] 3 WLR 764, [1978] 1 Lloyd's Rep 166, 6 Build LR 1, 10 Legal Decisions Affecting Bankers 50 that:

A performance bond is a new creature so far as we are concerned. It has many similarities to a letter of credit, with which of course we are very familiar. It has been long established that when a letter of credit is issued and confirmed by a bank, the bank must pay it if the documents are in order and the terms of the credit are satisfied. Any dispute between buyer and seller must be settled between themselves. The bank must honour the credit.

\subsection{Purpose of Performance Bond}

Rekhraj J in the case of Lotterworld Engineering \& Construction Sdn Bhd v Castle Inn Sdn Bhd \& Anor [1998] 7 MLJ 105 stated that the purpose of performance bond is as follows:

It is to be understood that the purpose of the performance bond in the construction industry is to perform the role of an effective safeguards against non-performance, inadequate performance or delayed performance and its production provides a security as readily available to be realized, when the prescribed event occurs, viz a viz simply failing to complete the work which had been contracted to carry out.

The purpose of a bond is therefore to provide the employer with some financial security in the form of a cash payable by the bank for the contractor's failure to perform his obligation under the construction contract.

\subsection{Performance Bond in Construction Contract}

Other than Clause 37(a) of the P.W.D. Form 203A (Rev. 10/83) Standard Form of Contract to be Used Where Bills of Quantities Form Part of the Contract, Clause 10 of the Conditions of Tendering in the Form of Tender (PWD 203B Rev. 1/82) states that "

The successful tenderer ...... shall so soon as it practicable but before the commencement of the Works deposit with the Superintending Officer ...... Performance Bond amounting to 5\% of the Contract Sum; .......

Another place where the requirement of performance bond is mandatory before commencement of contractor's works is under Clause 4 of the Letter of Acceptance (PWD 203D-Rev. 1/82), which states:

I wish to draw your attention to the Conditions of Tendering whereby as conditions precedent to the commencement of the Works, you are required to deposit with the Government or the Superintending Officer ...... Performance Bond amounting ...... (being 5\% of the Contract Sum) in cash or in the form of Treasury's Deposit, Banker's Draft or an approved banker's or Insurance Guarantee. ......

It is also unusual for private projects to require the contract to provide performance bond. Performance Bond, however, is the precondition for:

\section{- $\quad$ Taking possession of site}

By Clause 38(a) of the P.W.D. Form 203A (Rev. 10/83) Standard Form of Contract to be Used Where Bills of Quantities Form Part of the Contract it is made clear that even if possession of the Site has been given, the Contractor cannot commence work unless and until the performance bond and the insurance policies required under the Contract have been deposited with the Government or the Superintending Officer. Thus if the Contractor delays in depositing the performance bond or insurance, he does so at his own peril as the time available for the execution of the Works under the Contract would be ticking away (Fong, 2004a).

- Advance payment

The advance payment is paid to the Contractor upon application from him together with a bank or insurance guarantee for the amount of advance to be paid, and provided that he has returned the Letter of Acceptance duly signed and witnessed, and submitted the Performance Bond and the requisite insurance policies required by the Contract (Jabatan Kerja Raya, 1988).

\section{- $\quad$ First interim payment}

It is further provided that, other than for the first Interim Certificate, the Superintending Officer need not issue further Interim Certificates unless and until the Contractor has returned to the Government the Letter of Acceptance of Tender duly signed by the Contractor, and has deposited with him or the Government the insurance policies and performance bond required under clauses 33, 34, 36 and 37 of these Conditions in the P.W.D. Form 203A (Rev. 10/83) Standard Form of Contract to be Used Where Bills of Quantities Form Part of the Contract respectively (Fong, 2004).

\subsection{Construction of Performance Bond}

In order to determine the construction of a performance bond, Sir Denys Buckley stipulated in the case of $I E$ Contractors Ltd v Lloyds Bank PLC, and Rafidain Bank [1990] 2 Lloyd's Rep 496, SI Build LR 1 that: 
I am in entire agreement with the proposition that to discover what the parties intended should trigger the indemnity under the bond involves a straightforward exercise of construction, or interpretation, of the bond to discover the intention of the parties in that respect.

The Malaysian Superior courts have referred to and approved this approach in a number of cases. One of the case that the Superior Court approval of the above IE Contractors Ltd v Lloyds Bank PLC, and Rafidain Bank [1990] 2 Lloyd's Rep 496, SI Build LR 1 judgment is Esso Petroleum Malaysia Inc v Kago Petroleum Sdn Bhd [1995] 1 MLJ 149. Peh Swee Chin FCJ in delivering the grounds of judgment of the court said that "That the real issue of a performance bond is one of contractual interpretation was the unanimous view of three judges in the Court of Appeal in IE Contractors Ltd v Lloyds Bank plc and Rafidain Bank [1990] 2 Lloyd's Rep 496; (1991) 51 BLR 1."

\section{Method and Data Analysis}

By using the words 'Performance Bond', 67 cases for the past 20 years were downloaded from the Malayan Law Journal to be analyzed further. From the first reading and screening of the above cases, the judge of 25 cases did interpret the distinction between 'conditional' and 'unconditional' Performance Bond. Further screening was done from the 25 cases whereby only cases which the judge discussed on the wordings or phrase(s) of the Performance Bond will be further analyzed. From this, 15 cases were identified, as in summary in Table 1, to be further consumed as follows:

\subsection{Law Cases No.1}

In Suharta Development Sdn Bhd v United Overseas Bank (M) Bhd \& Anor [2005] 2 MLJ 762, Abdul Wahab Said Ahmad JC followed LEC Contractors (M) Sdn Bhd (formerly known as Lotterworld Engineering \& Construction Sdn Bhd) v Castle Inn Sdn Bhd \& Anor [2000] 3 MLJ 339, and hold this guarantee is an unconditional on demand guarantee.

\subsection{Law Cases No. 2}

In Daewoo Engineering \& Construction Co Ltd v The Titular Roman Catholic Archibishop of Kuala Lumpur [2004] 7 MLJ 136, Abdul Wahab Said Ahmad JC stated that "I agree with the learned defendant's counsel that the Letter of Guarantee seen in isolation is payable on demand because of the presence of the no contestation clause, i.e. 'notwithstanding any contestation or protest by the contractor or by the guarantor or by any third party."

\subsection{Law Cases No.3}

In Sime Engineering Sdn Bhd \& Anor v Public Bank Berhad [2004] 7 MLJ 475, Vincent Ng J stated that"The area of law concerning bank guarantees is well established; in the absence of fraud, the bank is obliged to pay on the guarantee promptly on demand."

\subsection{Law Cases No.4}

In Danaharta Managers Sdn Bhd v Huang Ee Hoe \& Ors [2002] 2 MLJ 424, Kang Hwee Gee J impliedly followed Mohamed Dzaiddin FCJ (as he then was) in Government of Malaysia v South East Asia Insurance Bhd [2000] 3 MLJ 625 , held at $\mathrm{p} 636 \mathrm{~B}$ that "In our judgment, on its true construction this Gerenti Pelaksanaan is and unconditional bond or an on demand bond and all that is required to activate it is a written demand (Easal)."

\subsection{Law Cases No.5}

As the previous case, in Government of Malaysia v South East Asia Insurance Bhd [2000] 3 MLJ 625, Mohamed Dzaiddin FCJ, following Ackner LJ in Easal (Commodities) Ltd v Oriental Credit Ltd; Banque Du Caire SA v Wells Fargo Bank NA [1985] 2 Lloyd's Rep 546, further stated that "Paragraph 1 is so drafted that the guarantor shall become liable merely when demand is made by the Government notwithstanding any contestation or protest by the contractor or the guarantor or by any third party. ... Therefore, on its true construction this Insurance Guarantee is an on demand performance bond."

\subsection{Law Cases No.6}

In LEC Contractors (M) Sdn Bhd (formerly known as Lotterworld Engineering \& Construction Sdn Bhd) v Castle Inn Sdn Bhd \& Anor [2000] 3 MLJ 339, Mokhtar Sidin JCA referred to several cases (Teknik Cekap Sdn Bhd v Public Bank Bhd [1995] 3 MLJ 449, Damatar Paints (P) Ltd v Indian Oil Corp AIR 1982 Delhi 57, Pesticides India v State Chemicals \& Pharmaceuticals Corp of India AIR 1982 Delhi 78, China Airlines Ltd v Maltran Air Corp Sdn Bhd (formerly known as Maltran Air Services Corp Sdn Bhd) and another appeal [1996] 2 MLJ 517, Esal (Commodities) Ltd and Esso Petroleum Malaysia Inc v Kago Petroleum Sdn Bhd), and therefore stated that "From the authorities we have referred earlier it is clear to us that to determine whether a performance bond is a conditional or unconditional bond, the court should not be concerned whether there was actual breach being committed or not. ... The bank has no choice but to pay the amount demanded. The first defendant is entitled to that sum not under the contract but under the performance bond." 


\subsection{Law Cases No.7}

In Fasda Heights Sdn Bhd v Soon Ee Sing Construction Sdn Bhd \& Anor [1999] 4 MLJ 199, Steve Shim J, while referring to Bocotra Construction Pte Ltd v A-G (No 2) [1995] 2 SLR 733 (CA). Esal (Commodities) Ltd \& Reltor Ltd v Oriental Credit Ltd \& Wells Fargo Bank NA [1985] 2 AC 546, IE Contractors Ltd v Lloyd's Bank plc \& Rafidain Bank and Teknik Cekap, stated that "In the circumstances, it was wrong for the second defendant to withhold or refuse to pay the monies to the plaintiff when the demand was made on the bank guarantee at the material time."

\subsection{Law Cases No.8}

In Lotterworld Engineering \& Construction Sdn Bhd v Castle Inn Sdn Bhd \& Anor [1998] 7 MLJ 165, Rekhraj J referred to Edward Owen Engineering Ltd v Barclays Bank International Ltd \& Anor [1978] QB 159 and Re Esal (Commodities) Ltd [1985] BCLC 450 stated that "This court will not therefore attribute an intention contrary to the plain meaning of the words used to attach liability towards payment upon demand."

\subsection{Law Cases No.9}

In Ramal Properties Sdn Bhd v East West-Umi Insurance Sdn Bhd [1998] 5 MLJ 233, Kamalanathan Ratnam JC, in referring Esal (Commodities) Ltd v Oriental Credit Ltd [1985] 2 Lloyd's Rep 546, Teknik Cekap Sdn Bhd v Public Bank Bhd [1995] 3 MLJ 449 and Esso Petroleum, stated that "... There was nothing there that could suggest that the demand was not proper, and for complying with the simple words there of making a claim by 'a demand in writing', the said letter was sufficiently compliant even though it was verbose."

\subsection{Law Cases No.10}

In China Airlines Ltd v Maltran Air Corp Sdn Bhd (formerly known as Maltran Air Services Corp Sdn Bhd) and Another Appeal [1996] 2 MLJ 517, Mohamed Dzaiddin FCJ (delivering the grounds of judgment of the court), after considering the cases of Esal (Commodities) Ltd, Esso Petroleum Malaysia Inc v Kago Petroleum Sdn Bhd [1995] 1 MLJ 149, Edward Owen Engineering Ltd v Barclays Bank International Ltd [1978] 1 QB 159 and RD Harbottle (Mercantile) Ltd v National Westminster Bank Ltd [1978] 1 QB 146, stated that "In her grounds of judgment, the learned judge recognized that AC4 is an 'on demand guarantee'."

\subsection{Law Cases No.11}

In Esso Petroleum Malaysia Inc v Kago Petroleum Sdn Bhd [1995] 1 MLJ 149, Peh Swee Chin FCJ (delivering the grounds of judgment of the court) following the case of IE Contractors [1989] 2 Lloyd's Rep 205 stated that "On the type of such pure on demand performance bonds, the issuer should unquestionably pay on demand except in the case of fraud."

\subsection{Law Cases No.12}

In Nik Sharifuddin Bin Nik Kadir v Mohaiyani Securities Sdn Bhd [1994] 3 MLJ 551, Zakaria Yatim J, with the help of IE Contractors 51 BLR 5, Australasian Conference Association Ltd v Mainline Constructions Pty Ltd (In Liquidation) \& Ors (1978) 141 CLR 335, Jowitt v Callaghan (1938) 38 SR (NSW) 512 and Re Conley [1938] 2 All ER 127, stated that "In my opinion, the banker's guarantee is not an unconditional guarantee."

\subsection{Law Cases No.13}

In Kirames Sdn Bhd v Federal Land Development Authority [1991] 2 MLJ 198, Zakaria Yatim J stated that "It is clear that the above document is a guarantee given by Jerneh Insurance Corp Sdn Bhd on behalf of the plaintiff for the due performance of the contract dated 3 October 1985. The guarantee is an 'on-demand' guarantee."

\subsection{Law Cases No.14}

In Patel Holdings Sdn Bhd v Estet Pekebun Kecil \& Anor [1989] 1 MLJ 190, Wan Adnan J stated followed Edward Owen Engineering Ltd v Barclays Bank International Ltd [1978] QB 159 that "The bank must pay according to its guarantee, on demand, if so stipulated, without proof or conditions. The only exception is when there is clear fraud of which the bank has notice."

\subsection{Law Cases No.15}

In Teknik Cekap Sdn Bhd v Public Bank Bhd [1995] 3 MLJ 449, in also referred to several cases (IE Contractors Ltd v Lloyds Bank plc and Rafidain Bank (1990) 51 BLR 1, Edward Owen Engineering Ltd v Barclays Bank International Ltd \& Anor [1978] 1 All ER 976; [1977] 3 WLR 764, Kirames Sdn Bhd v Federal Land Development Authority [1991] 2 MLJ 198, Esso Petroleum Malaysia Inc v Kago Petroleum Sdn Bhd [1995] 1 MLJ 149 and Esal (Commodities) and Relton v Oriental Credit and Wells Fargo Bank NA [1985] 2 Lloyd's Rep 546), Shaik Daud JCA stated that "If the sub-contractor (unless relieved from the performance of any clause of the contract or by statute or by the decision of a tribunal of competent jurisdiction) shall in any respect fail to execute the contract or commit any breach of his obligations thereunder then the guarantor shall pay to the contractor up to and not exceeding the sum of RM422,000 
(Malaysian Ringgit four hundred twenty two thousand) only representing $10 \%$ of the contract value or such part thereof on the contractor's demand notwithstanding any contestation or protest by the sub-contractor or by the guarantor or by any other third party, provided always that the total of all partial demands so made shall not exceed the sum of RM422,000 (Malaysian Ringgit four hundred twenty two thousand) only and that the guarantor's liability to pay the contractor as aforesaid shall correspondingly be reduced proportionate to any partial demand having been made as aforesaid.

\section{Conclusion}

The judgment of fifteen law cases had been analysed to differentiate the conditionality of the performance bond by its wordings. Some of the cases held that the performance bonds were conditional performance bond and some of them held the performance bond to be unconditional 'on-demand' performance bond. From Table 1, it seems that most of the judges referred to the surrounding five law cases which were discussed below to interpret whether the wording of the performance bonds are conditional or unconditional 'on-demand' bonds. However, some interesting conclusion can be made from the words in the performance bond.

The first and mostly referred is Easal (Commodities) Ltd \& Reltor Ltd v Oriental Credit Ltd \& Wells Fargo Bank NA [1985] 2 AC 546 which gives the conclusion that there are three possible meanings for the words used in the performance bond, i.e. no more a written demand is required; the demand must assert a failure to perform the contract; and there must in fact have been a failure to perform. However, most of the judge rejected the last possible meaning of the words used.

In interpreting the words of the performance bond, the second case of Esso Petroleum Malaysia Inc v Kago Petroleum Sdn Bhd [1995] 1 MLJ 149 referred the third case of IE Contractors Ltd v Lloyd's bank plc and Rafidain Bank [1990] 2 Lloyd's Rep 296, which a conclusion can be made that there was a bias or presumption in favour of the construction that performance bond was to be conditioned upon documents rather than facts.

The fourth case is also the famous Malaysian case of Teknik Cekap Sdn Bhd v Public Bank Bhd [1995] 2 Lloyd's Rep 296 which held that because the performance bond because the bond began with the words 'if the subcontractor ... shall in any respect fail to execute the contract or commit any breach of his obligations thereunder then the guarantor shall pay ...', the bond was a conditional bond.

Last but not least, the case of Edward Owen Engineering Ltd v Barclays Bank International Ltd [1978] 1 QB 159 stressed the general nature of a performance bond that a bank is not concerned in the least with the relations between the supplier and the customer nor with the question whether the supplier has performed his contractual obligation or not, nor with the question whether the supplier is in default or not, the only exception being where there is clear evidence both of fraud and of the bank's knowledge of that fraud.

However, Steve Shin J in Fasda Heights Sdn Bhd v Soon Ee Sing Construction Sdn Bhd \& Anor [1999] 4 MLJ 199 made quite good critics as to the wordings of the performance bond. He said that there are two 'conditions' that the bank must adhere to. The first is that the demand is in writing. It has been said that such a 'condition' is merely to regulate the right to call on the guarantee and is therefore purely a procedural matter. It does not render a guarantee conditional in the true sense. The second is that the contractor fails to execute the works and/or in breach of the contract. Three possible meanings for the words used: (i) that no more than a written demand was required; (ii) that the demand must assert a failure to perform the contract; or (iii) that there must in fact have been a failure to perform. Most of the courts unanimously rejected the third solution.

Kamalanathan Ratnam JC in Ramal Properties Sdn Bhd v East West-Umi Insurance Sdn Bhd [1998] 5 MLJ 233 also made quite interesting statements towards the meaning of the words in the performance bond. He said that the wordings of 'If the contractor ... shall in any respect fail to execute the contract or commit any breach of his obligations thereunder, then the guarantor will indemnify and pay the principal ...' renders the performance bond to be an on-demand performance bond which is only conditional upon the beneficiary asserting the basis of the claim upon the issuer of the bond contending that there has been a breach of contract.

Lastly, to be an undisputed meaning of the words in the performance bond, the performance bond itself should be either purely conditional or purely unconditional 'on-demand' bond. The best examples for this are in the cases of Esso Petroleum Malaysia Inc v Kago Petroleum Sdn Bhd [1995] 1 MLJ 149 and IE Contractors Ltd v Lloyd's bank plc and Rafidain Bank [1990] 2 Lloyd's Rep 296 which respectively as follows:

"... we hereby unconditionally and irrevocably guarantee the payment to EPMI"

"We undertake to pay you, unconditionally, the said amount on demand, being your claim for damages brought about by the abovenamed principal."

\section{References}

Abdul-Rashid, K. (2004). Guarantee Against Non-Performance of Construction Contract by the Contractor: 
Performance Guarantee Sum versus Performance Bond, Seminar, $1^{\text {st }}$ International Conference, Toronto Canada, May 272004 - May 28 2004, World of Construction Project Management.

Fong, C.K. (2004a). Law and Practice of Construction Contracts, $3^{\text {rd }}$ Edition, Sweet \& Maxwell Asia, Singapore.

Fong, L.C. (2004b). The Malaysian PWD Form of Construction Contract, Sweet \& Maxwell Asia, Petaling Jaya.

Ismail, N. (2007). Performance Bond and An Injunction, Master's Project Report (Dissertation), Universiti Teknologi Malaysia.

Jabatan Kerja Raya (1988). A Guide on the Administration of Public Works Contracts, Ibu Pejabat JKR Malaysia.

Martin, E.A. (2003). A Dictionary of Law, $5^{\text {th }}$ Edition reissued with new covers, Oxford University Press, Oxford.

Murdoch, J. and Hughes, W. (2000). Construction Contracts - Law and Management, $3^{\text {rd }}$ Edition, Spon Press, London.

P.W.D. Form 203 A (Rev. 10/83) Standard Form of Contract to be Used Where Bills of Quantities Form Part of the Contract.

Radhakrihnan, S. (1999). Legal Aspects of Insurance for Engineering Projects, Article, [1999] 1 MLJ cxxx; [1999] 1 MLJA 130.

Robinson, N.M., Lavers, A.P., Heng, G.T.K. and Chan, R. (1996). Construction Law in Singapore and Malaysia, Second Edition, Butterworths Asia, Singapore. 
Table 1. Summary of Law Case Analysis

\begin{tabular}{|c|c|c|c|c|c|c|c|c|c|c|c|c|c|c|c|c|}
\hline \multirow[b]{2}{*}{ Cases Referred } & \multicolumn{16}{|c|}{ Analysed Law Cases } \\
\hline & 1 & 2 & 3 & 4 & 5 & 6 & 7 & 8 & 9 & 10 & 11 & 12 & 13 & 14 & 15 & 恶 \\
\hline $\begin{array}{l}\text { Australian Conference } \\
\text { Assoc. Ltd v Mainline } \\
\text { Constructions Pty Ltd }\end{array}$ & & & & & & & & & & & & 1 & & & & 1 \\
\hline $\begin{array}{l}\text { Banque Du Caire SA v } \\
\text { Wells Fargo Bank NA }\end{array}$ & & & & & 1 & & & & & & & & & & & 1 \\
\hline $\begin{array}{l}\text { Bocotra Construction Pte } \\
\text { Ltd v A-G (No. 2) }\end{array}$ & & & & & & & 1 & & & & & & & & & 1 \\
\hline $\begin{array}{l}\text { China Airlines Ltd v } \\
\text { Maltran Air Corp S/B }\end{array}$ & & & & & & 1 & & & & & & & & & & 1 \\
\hline $\begin{array}{l}\text { Damatar Paints (P) Ltd v } \\
\text { Indian Oil Corp }\end{array}$ & & & & & & 1 & & & & & & & & & & 1 \\
\hline $\begin{array}{l}\text { Easal (Commodities) Ltd } \\
\text { v Oriental Credit Ltd }\end{array}$ & & & & 1 & 1 & 1 & 1 & 1 & 1 & 1 & & & & & 1 & 8 \\
\hline $\begin{array}{l}\text { Edward Owen Eng. Ltd v } \\
\text { Barclays Bank (I) Ltd }\end{array}$ & & & & & & & & 1 & & 1 & & & & 1 & 1 & 4 \\
\hline $\begin{array}{l}\text { Esso Petroleum Malaysia } \\
\text { v Kago Petroleum S/B }\end{array}$ & & & & & & 1 & & & 1 & 1 & & & & & 1 & 4 \\
\hline $\begin{array}{l}\text { Government of Malaysia } \\
\text { v S. E. A. Insurance Bhd }\end{array}$ & & & & 1 & & & & & & & & & & & & 1 \\
\hline $\begin{array}{l}\text { IE Contractors Ltd v } \\
\text { Lloyd's Bank plc }\end{array}$ & & & & & & & 1 & & & & 1 & & & & 1 & 3 \\
\hline Jowitt v Callaghan & & & & & & & & & & & & 1 & & & & 1 \\
\hline $\begin{array}{l}\text { Kirames S/B v Federal } \\
\text { land Dev Authority }\end{array}$ & & & & & & & & & & & & & & & 1 & 1 \\
\hline $\begin{array}{l}\text { LEC Contractors (M) } \\
\mathrm{S} / \mathrm{B} \text { v Castle Inn S/B }\end{array}$ & 1 & & & & & & & & & & & & & & & 1 \\
\hline $\begin{array}{l}\text { Pesticides India v State } \\
\text { Chemicals of India }\end{array}$ & & & & & & 1 & & & & & & & & & & 1 \\
\hline $\begin{array}{l}\text { RD Harbottle Ltd v Nat. } \\
\text { Westminster Bank Ltd }\end{array}$ & & & & & & & & & & 1 & & & & & & 1 \\
\hline Re Conley & & & & & & & & & & & & 1 & & & & 1 \\
\hline $\begin{array}{l}\text { Teknik Cekap S/B v } \\
\text { Public Bank Bhd }\end{array}$ & & & & & & 1 & 1 & & 1 & & & & & & & 3 \\
\hline \multicolumn{17}{|l|}{ Judgment } \\
\hline Conditional & & & & & & & & & & & & 1 & & & 1 & 2 \\
\hline Unconditional & 1 & 1 & 1 & 1 & 1 & 1 & 1 & 1 & 1 & 1 & 1 & & 1 & 1 & & 13 \\
\hline
\end{tabular}




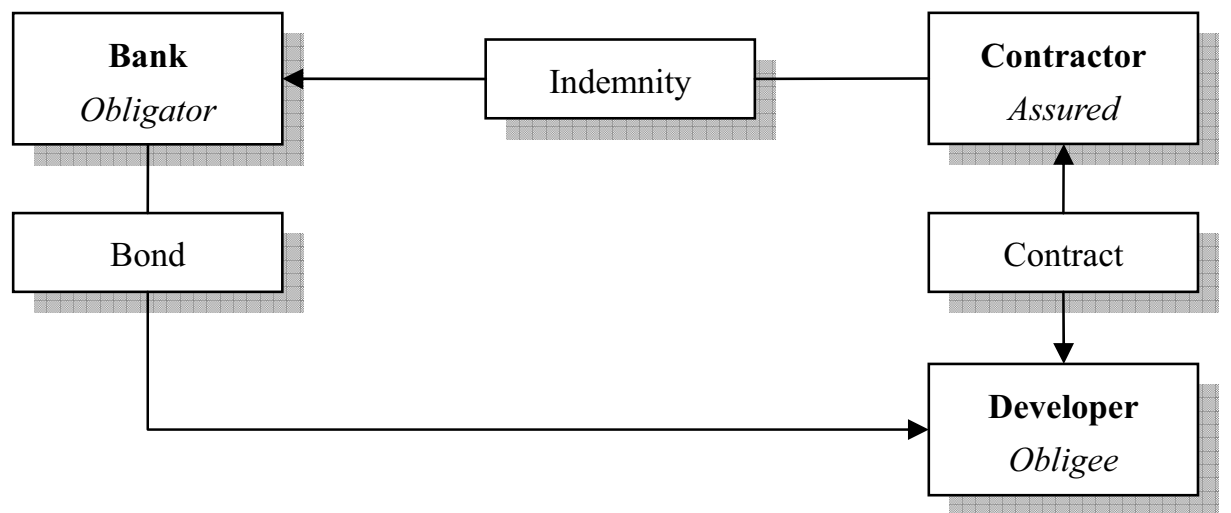

Figure 1. Relationships of Parties to a Bond and the Underlying Contract

(Source: Fong, 2004b)

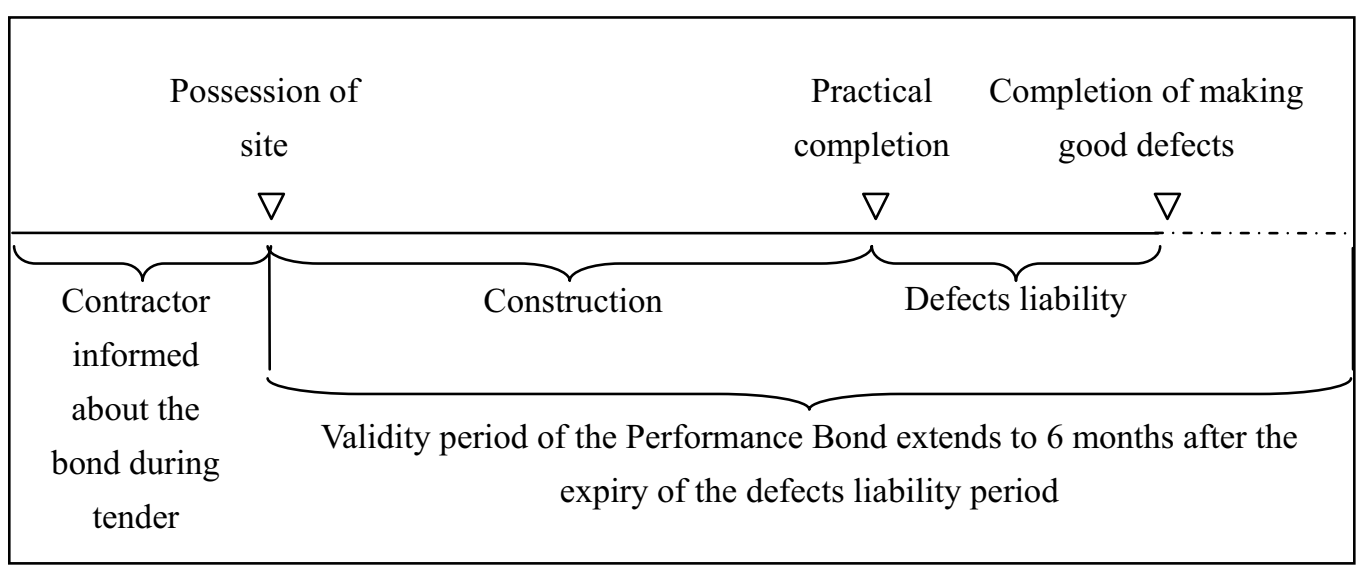

Figure 2. Time line indicating the validity period of the performance bond

(Source: Abdul-Rashid, 2004) 